\title{
Peningkatan komponen dan kualitas hasil nanas melalui aplikasi kalsium dan etilen sintetik di daerah kering dan panas Kabupaten Malang
}

Sari. Kalsium dan etilen diketahui pada penelitian terdahulu dapat meningkatkan kualitas hasil nanas (Ananas comosus (L.) Merr.), namun perlu penelitian untuk memvalidasi hasil penelitian di tempat yang lain. Beberapa petani membudidayakan nanas di pesisir selatan Malang yang relatif kering dan panas.Kalsium klorida (sebagai sumber kalsium) dan Ethephon (sebagai etilen sintetik) digunakan dalam penelitian ini. Penelitian ini bertujuan untuk mendapatkan kapan waktu aplikasi $\mathrm{CaCl}_{2}$ yang tepat, takaran dosis $\mathrm{CaCl}_{2}$ dan kapan waktu aplikasi ethephon yang tepat untuk meningkatkan kualitas dari buah nanas di daerah kering dan panas di Kabupaten Malang. Penelitian ini dilaksanakan bulan Oktober 2019 - Maret 2020 di Ngajum, Kabupaten Malang. Penelitian dilakukan menggunakan Rancangan Petak Petak Terbagi dengan 3 ulangan. Petak utama ialah waktu aplikasi $\mathrm{CaCl}_{2}$ yang terdiri dari 3 taraf (100 hsp, 130 hsp, 100 hsp + 130 hsp). Anak petak ialah dosis $\mathrm{CaCl}_{2}$ yang terdiri dari 3 taraf $\left(55 \mathrm{~kg} \mathrm{ha}^{-1}, 80 \mathrm{~kg} \mathrm{ha}^{-1}\right.$ dan $\left.105 \mathrm{~kg} \mathrm{ha}^{-1}\right)$. Anak-anak petak ialah dosis ethephon yang terdiri dari 2 taraf $\left(0 \mathrm{~L} \mathrm{ha}^{-1}\right.$ dan $\left.3 \mathrm{~L} \mathrm{ha}^{-1}\right)$. Parameter pengamatan yang diamati yaitu panjang buah, bobot buah, dan kadar air buah. Hasil penelitian menunjukkan bahwaterdapat pengaruh interaksi antara dosis dan waktu aplikasi $\mathrm{CaCl}_{2}$ terhadap kadar air buah. Aplikasi $\mathrm{CaCl}_{2}$ secara mandiri menghasilkan bobot buah yang berbeda nyata dan lebih besar dibandingkan dengan kontrol. Aplikasi Ethephon tidak mempengaruhi komponen dan kualitas hasil nanas.

Kata kunci : Buah nanas $\cdot \mathrm{CaCl}_{2} \cdot$ Etephon

\section{Increasingof yield component and quality of pineapple through the application of calcium and synthetic ethylen in the dry and hot climates of Malang District}

\begin{abstract}
Calcium and ethylene were known in previous study to improve the yield quality of pineapple (Ananas comosus (L.) Merr.), but it is necessary to validate those research in another place. Farmers cultivated pineapple in south coast of Malang whichare relatively dry and hot. Calcium chloride (as a source of calcium) and Ethephon (as synthetic ethylene) were used in this study. This study aims to find the correct application time of $\mathrm{CaCl}_{2}, \mathrm{CaCl}_{2}$ dosage, and ethephon application to improve the quality of pineapple fruit in dry and hot climates of Malang District. This research was conducted in October 2019 March 2020 in Ngajum, Malang Regency. The research usedSplit Split Plot Design with 3 replications. The main plot was the application times of $\mathrm{CaCl}_{2}$ which consisted of 3 levels $(100 \mathrm{hsp}, 130 \mathrm{hsp}$, and 100 hsp + $130 \mathrm{hsp}$ ). The subplot was the doses of $\mathrm{CaCl}_{2}$ which consisted of 3 levels ( $55 \mathrm{~kg} \mathrm{ha}^{-1}, 80 \mathrm{~kg} \mathrm{ha}^{-1}$ and $105 \mathrm{~kg}$ $\left.\mathrm{ha}^{-1}\right)$.The sub-subplots wasethephon doses which consisted of 2 levels $\left(0 \mathrm{~L} \mathrm{ha}^{-1}\right.$ and $\left.3 \mathrm{~L} \mathrm{ha}^{-1}\right)$. The observed parameters were fruit length, fruit weight, and fruit moisture content.The results showed that there were interaction effect between doses and application times of of $\mathrm{CaCl}_{2}$ on fruit moisture content. Single effect of $\mathrm{CaCl} 2$ affected fruit weights significantly, greater than control. Single effect of Ethephon did not affect the yield components and quality of pineapple.
\end{abstract}

Keywords : $\mathrm{CaCl}_{2} \cdot$ Etephon $\cdot$ Pineapple

Diterima : 1 Oktober 2020, Disetujui : 10 April 2021, Dipublikasikan : 16 April 2021 doi: https:// doi.org/10.24198/kultivasi.v20i1.29419

Karamina, H. ${ }^{1} \cdot$ A.T. Murti ${ }^{2}$ T. Mujoko ${ }^{3}$

1 Program Studi Agroteknologi, Fakultas Pertanian, Universitas Tribhuwana Tunggadewi

2 Program Studi Peternakan, Fakultas Pertanian, Universitas Tribhuwana Tunggadewi

3 Program studi Agroteknologi, Fakultas Pertanian, UPN Veteran Jatim Surabaya

Korespondensi: hidayatikaramina@yahoo.com 


\section{Pendahuluan}

Nanas merupakan buah di wilayah tropika dan sub tropika. Data dari Badan Pusat Statistik (2017) menyatakan bahwa produksi nanas di Indonesia pada tahun 2016 mencapai 1.396.153 ton dan tahun 2017 mencapai 1.795.986 ton ratarata persentase pertumbuhan hasil produksi mencapai 28,64\%. Pesisir selatan Kabupaten Malang merupakan sentra produksi buah nanas di Kabupaten Malang dengan karakteristik suhu relatif tinggi dan curah hujan relatif rendah. Permasalahan saat ini yang dialami oleh produsen nanas yaitu adalah masalah dari hasil dan kualitas buah. Untuk mengatasi permasalahan tersebut, perlu dilakukan upaya peningkatan komponen hasil dan kualitas buah nanas.

Salah satu upaya yang dapat dilakukan untuk meningkatkan kualitas buah ialah aplikasi $\mathrm{CaCl}_{2} \cdot \mathrm{CaCl}_{2}$ merupakan salah satu bahan kimia yang dapat digunakan untuk mempertahankan tekstur buah agar tidak mudah busuk. Kalsium telah diketahui efektif dalam mempertahankan ketegaran tekstur buah (Mirandaet al., 2019). Pada salah satu bagian dinding sel buah yaitu lamela tengah, merupakan daerah yang banyak mengandung pektin yang apabila berinteraksi dengan $\mathrm{Ca}^{2+}$ akan membentuk Ca pektat, yang berperan dalam menambah keterikatan antar sel (Mishra, 2002).

Aplikasi $\mathrm{CaCl}_{2}$ diketahui dapat mempertahankan tekstur buah karena larutan $\mathrm{CaCl}_{2}$ masuk ke dalam pori buah dan akan bekerja pada dinding sel dalam menjembatani galakturonat pada pektin sehingga ketegaran tekstur buah tetap terjaga. Tekstur buah yang keras akan membuat mikroorganisme penyebab busuk buah sulit melakukan infeksi (Mishra, 2002).

Hasil penelitian Basuki et al. (2009) menunjukkan bahwa aplikasi $\mathrm{CaCl}_{2}$ dengan dosis $50 \mathrm{~kg} \mathrm{ha}^{-1}$ sebanyak 3 dan 4 kali aplikasi pada umur 1 sampai 4 bulan setelah pembungaan dapat menekan intensitas penyakit buah terutama marbling dan brown spot serta meningkatkan kadar Ca buah yang secara linier juga dapat meningkatkan kekerasan buah pada nanas. Selain aplikasi $\mathrm{CaCl}_{2}$, aplikasi etilen dalam bentuk ethephon juga telah terbukti dapat meningkatkan kualitas buah nanas dengan menurunkan persentase penyakit buah.
Hasil penelitian Bondad (2006) menunjukkan bahwa aplikasi ethephon yang dilakukan pada umur 135 hari setelah pembungaan (5 hari sebelum panen alami) dengan dosis 2,5L ha-1 sangat nyata menurunkan penyakit cork spot pada buah nanas. Aplikasi ethephon berfungsi untuk mempercepat kemasakan buah dengan seragam, serta mendapatkan buah yang masak sebelum mikroorganisme patogenik berkembang dalam buah (Sidauruk et al., 2013). Aplikasi ethephon berpengaruh nyata memberikan kemasakan buah yang lebih seragam dibanding dengan buah masak alami (Bondad, 2006).

Astuti et al. (2013) sebenarnya telah berhasil melakukan penelitian untuk meningkatkan kualitas buah nanas menggunakan kombinasi perlakuan waktu aplikasi $\mathrm{CaCl}_{2}$, dosis $\mathrm{CaCl}_{2}$ dan aplikasi ethephon di daerah Lampung dengan karakteristik curah hujan lebih tinggi dan suhu lebihrendah daripada pesisir selatan Malang. Suhu minimum dan maksimum di Lampung masing-masing adalah $21^{\circ} \mathrm{C}$ dan $33,8^{\circ} \mathrm{C}$, sementara rata-rata Rata-rata suhu minimum di pesisir selatan Malang adalah $23^{\circ} \mathrm{C}$ dan suhu maksimum $40{ }^{\circ} \mathrm{C}$; curah hujan di Lampung adalah $2808,5 \mathrm{~mm}$ dengan distribusi hujan per tahun adalah 120 hari,sementara curah hujan rata-rata $1596 \mathrm{~mm}$ dengan distribusi hujan 84,85 hari per tahun (Istiqomah, 2017; Pemkab Malang, 2010). Curah hujan pesisir selatan Malang masuk dalam kriteria syarat tumbuh tanaman nanas, namun suhu terlalu tinggi; sebaliknya curah hujan di Lampung di luar kriteria curah hujan optimum, namun suhu termasuk optimum (Hadiyati dan Indriyani, 2008). Hal ini dapat menyebabkan perbedaan respons tanaman terhadap perlakuan ethephon dan $\mathrm{CaCl}_{2}$. Oleh karena itu, perlu dilakukan penelitian Astuti et al. (2013) kembali dalam bentuk modifikasi untuk meningkatkan hasil dan kualitas buah nanas di pesisir selatan Malang.

\section{Bahan dan metode}

Penelitian dilaksanakan di lahan petani yang terletak di Ngajum, Kabupaten Malang pada ketinggian 46 meter di atas permukaan laut dengan jenis tanah ultisol. Penelitian dilaksanakan pada bulan Oktober 2019 hingga Maret 2020. Adapun alat yang digunakan dalam 
penelitian ini ialah sprayer, penggaris/ meteran, pengaduk, pisau, cangkul kecil, plot nama dan kamera. Bahan yang digunakan ialahbibit nanas varietas Smooth Cayenne, $\mathrm{CaCl}_{2}$, ethephon, air,pupuk urea, pupuk SP36, pupuk $\mathrm{KCl}$ dan $\mathrm{K}_{2} \mathrm{SO}_{4}$. Bahan aktif herbisida yang digunakan ialah Amitrin dan Diuron. Bahan aktif pestisida yang digunakan ialah Propoxur, Fosetyl Al, Cypemethrin, Propikanozal, dan Indostic sebagai bahan perekat. Penelitian dilakukan menggunakan Rancangan Petak Petak Terbagi (RPPT) dengan 3 ulangan.

Petak utama ialah waktu aplikasi $\mathrm{CaCl}_{2}$ yang terdiri dari 3 taraf, yaitu :

- 100 hari setelah perlakuan (hsp) (W100),

- 130 hsp (W130), dan

- 100 dan 130 hsp (W100+ 130).

Anak petak ialah dosis $\mathrm{CaCl}_{2}$ yang terdiri dari 3 taraf yaitu:

- $55 \mathrm{~kg} \mathrm{ha}^{-1}$ (C55),

- $80 \mathrm{~kg} \mathrm{ha}^{-1}(\mathrm{C} 80)$, dan

- $105 \mathrm{~kg} \mathrm{ha}^{-1}$ (C105).

Anak petak ialah dosis ethephon yang terdiri dari 2 taraf, yaitu:

- $0 \mathrm{~L} \mathrm{ha}^{-1}$ (E0)

- $3 \mathrm{~L} \mathrm{ha}^{-1}$ (E3).

Persiapan bahan $\mathrm{CaCl}_{2}$ dilakukan dengan cara mencampurkan $\mathrm{CaCl}_{2}$ sesuai dengan masing-masing dosis perlakuan (55 kg ha-1, 80 $\mathrm{kg} \mathrm{ha}^{-1}$ dan $105 \mathrm{~kg} \mathrm{ha}^{-1}$ ) dengan air $2000 \mathrm{Lha}^{-1}$. Aplikasi $\mathrm{CaCl}_{2}$ dilakukan pada $100 \mathrm{hsp}, 130 \mathrm{hsp}$ dan dua kali waktu aplikasi yaitu 100 hsp dan 130 hsp sesuai dengan masing-masing perlakuan. Aplikasi dilakukan dengan menggunakan alat sprayer.

Sedangkan persiapan ethepon dilakukan dengan cara mencampurkan ethephon 3 Lha $^{-1}$ dengan air 2000 L. Aplikasi ethephon dilakukan sore hari pada umur 148 hari setelah pembungaan. Aplikasi ethephon dilakukan dengan menggunakan alat sprayer.

Pada perlakuan aplikasi $\mathrm{CaCl}_{2}$ dan ethephon, panen dilakukan 3 hari setelah aplikasi yaitu 151 hari setelah pembungaan. Pada tanaman kontrol, buah dipanen pada umur 155 hari setelah pembungaan dan pada perlakuan aplikasi $\mathrm{CaCl}_{2}$ tanpa aplikasi ethephon buah dipanen pada umur 160 hari setelah pembungaan. Panen dilakukan secara manual dengan cara memetik buah nanas dari tanaman. Adapun parameter pengamatan meliputi panjang buah, bobot buah, dan kadar air buah.
Data pengamatan yang diperoleh dianalisis dengan menggunakan analisis ragam (uji F) pada taraf nyata 5\%. Selanjutnya untuk mengetahui perbedaan diantara perlakuan dilakukan dengan Uji Beda Nyata Terkecil (BNT) pada taraf 5\%. Perbedaan pengaruh perlakuan dan kontrol dianalisis dengan menggunakan uji orthogonal kontras.

\section{Hasil dan Pembahasan}

Panjang buah. Buah merupakan komponen hasil dari budidaya tanaman nanas. Hasil penelitian menunjukkan bahwa tidak terjadi interaksi antara perlakuan waktu aplikasi $\mathrm{CaCl}_{2}$, dosis $\mathrm{CaCl}_{2}$, dan aplikasi ethephon tehadap bobot dan panjang buah nanas. Selanjutnya jika ditinjau dari pengaruh mandiri setiap taraf perlakuan terhadap kontrol menunjukkan bahwa tanaman yang diperlakukan aplikasi $\mathrm{CaCl}_{2}$ dan ethephon menghasilkan panjang buah yang tidak berbeda nyata dibandingkan dengan kontrol. Data panjang buah disajikan pada Tabel 1.

Tabel 1. Rata-rata panjang buah $(\mathrm{cm})$ akibat pengaruh perlakuan waktu aplikasi $\mathrm{CaCl}_{2}$, dosis $\mathrm{CaCl}_{2}$, aplikasi ethephon dan perbandingan perlakuan dengan kontrol.

\begin{tabular}{|c|c|}
\hline Perlakuan & Panjang buah $(\mathrm{cm})$ \\
\hline \multicolumn{2}{|l|}{ Waktu aplikasi $\mathrm{CaCl}_{2}$ (hsp) } \\
\hline 100 & 16,12 \\
\hline $100+130$ & 16,15 \\
\hline 130 & 16,75 \\
\hline BNT 5\% & $0,66 \mathrm{tn}$ \\
\hline \multicolumn{2}{|l|}{ Dosis $\mathrm{CaCl}_{2}\left(\mathrm{~kg} \cdot \mathrm{ha}^{-1}\right)$} \\
\hline 55 & 16,29 \\
\hline 80 & 16,27 \\
\hline 105 & 16,46 \\
\hline BNT 5\% & $0,34 \mathrm{tn}$ \\
\hline \multicolumn{2}{|l|}{ Dosis Ethephon (1.ha-1) } \\
\hline 0 & 16,40 \\
\hline 3 & 16,27 \\
\hline BNT 5\% & $0,4 \mathrm{tn}$ \\
\hline \multicolumn{2}{|l|}{ Kontrol vs Perlakuan } \\
\hline Kontrol & 16,08 \\
\hline Perlakuan & 16,34 \\
\hline BNT 5\% & $0,3 \mathrm{tn}$ \\
\hline $\begin{array}{l}\text { Keterangan :Angka yang } \\
\text { menunjukkan tidak berbeda } \\
\text { taraf nyata } 5 \% \text {, tn = tidak berb } \\
\text { dengan taraf nyata } 5 \% \text {, } \\
\text { pembungaan. }\end{array}$ & $\begin{array}{l}\text { idak diikuti huruf } \\
\text { ada uji BNT dengan } \\
\text { la nyata pada uji BNT } \\
\mathrm{sp}=\text { hari setelah }\end{array}$ \\
\hline
\end{tabular}


Syah (2015) mengemukakan bahwa besarnya diameter buah juga disebabkan oleh panjang buah pada tanaman. Menurut Leal and Coppens (2006) diameter buah dan panjang buah memiliki hubungan dimana semakin tinggi panjang buah maka semakin besar diameter buah sehingga semakin besar pula produktivitas. Diameter buah Bartholomew (2003) dan panjang buah Cahyono et al. (2014) bergantung pada kepadatan tanaman sehingga etilen dan kalsium tidak terlalu berpengaruh. Hal yang berbeda pada penelitian Rai et al. (2014), bahwa pemberian ethepon dengan konsentrasi 0, 100, dan 200 ppm memberikan pengaruh yang sama terhadap peningkatan panjang batang tanaman mentimun. Sidauruk et al. (2013) juga menyatakan bahwa semakin tinggi nilai dari konsentrasi dosis ethepon maka panjang tanaman akan semakin pendek. Hal ini disebabkan oleh aplikasi ethepon yang dihasilkan akan menghambat proses pemanjangan sel batang tanaman sehingga semakin tinggi konsentrasi aplikasi dosis ethepon akan menghambat kerja dari hormon auksin yang berguna untuk stimulasi pertumbuhan sel tanaman.

Bobot buah. Hasil analisis ragam menunjukkan bahwa tidak terjadi interaksi antara perlakuan waktu aplikasi $\mathrm{CaCl}_{2}$, dosis $\mathrm{CaCl}_{2}$, dan aplikasi ethephon terhadap bobot buah. Perlakuan aplikasi $\mathrm{CaCl}_{2}$ dan dosis $\mathrm{CaCl}_{2}$ berpengaruh terhadap bobot buah, sedangkan perlakuan aplikasi ethephon tidak berpengaruh terhadap bobot buah. Data bobot buah disajikan pada Tabel 2.

Tabel 2 menunjukkan bahwa perlakuan dua kali aplikasi $\mathrm{CaCl}_{2}$ pada 100 dan $130 \mathrm{hsp}$ menghasilkan bobot buah tertinggi. Dosis $\mathrm{CaCl}_{2}$ $105 \mathrm{~kg} \mathrm{ha}^{-1}$ menghasilkan bobot buah yang berbeda nyata dan lebih besar dibandingkan dengan dosis $55 \mathrm{~kg}^{-1}$, tetapi dosis $\mathrm{CaCl}_{2} 105$ $\mathrm{kg}$ ha-1 $^{-1}$ menghasilkan bobot buah yang tidak berbeda nyata dengan dosis $\mathrm{CaCl}_{2} 80 \mathrm{~kg}$ ha-1. Pada perlakuan aplikasi ethephon dengan dosis 3 Lha $^{-1}$ menghasilkan bobot buah yang tidak berbeda nyata dengan perlakuan tanpa aplikasi ethephon. Berdasarkan uji orthogonal kontras, pengaruh perlakuan terhadap kontrol menunjukkan bahwa tanaman yang diperlakukan dengan aplikasi $\mathrm{CaCl}_{2}$ dan ethephon menghasilkan bobot buah yang berbeda nyata dan lebih besar dibandingkan dengan kontrol.
Tabel 2. Rata-rata bobot buah (g) akibat pengaruh perlakuan waktu aplikasi $\mathrm{CaCl}_{2}$, dosis $\mathrm{CaCl}_{2}$, dan aplikasi ethephon dan perbandingan perlakuan dengan kontrol.

\begin{tabular}{|c|c|}
\hline Perlakuan & Bobot buah $(\mathrm{g})$ \\
\hline \multicolumn{2}{|c|}{ Waktu aplikasi $\mathrm{CaCl}_{2}$ (hsp) } \\
\hline 100 & 1473,55 a \\
\hline $100+130$ & $1619,18 \mathrm{~b}$ \\
\hline 130 & 1479,31 a \\
\hline BNT 5\% & 76,92 \\
\hline \multicolumn{2}{|c|}{ Dosis $\mathrm{CaCl}_{2}\left(\mathrm{~kg} \mathrm{ha}^{-1}\right)$} \\
\hline 55 & 1484,97 a \\
\hline 80 & $1536,59 \mathrm{ab}$ \\
\hline 105 & $1550,48 \mathrm{~b}$ \\
\hline BNT 5\% & 52,48 \\
\hline \multicolumn{2}{|c|}{ Aplikasi Ethephon $\left(1\right.$ ha $\left.^{-1}\right)$} \\
\hline 0 & 1522,67 \\
\hline 3 & 1525,36 \\
\hline BNT 5\% & $4.41 \mathrm{tn}$ \\
\hline \multicolumn{2}{|c|}{ Kontrol vs Perlakuan } \\
\hline Kontrol & 1439,12 a \\
\hline Perlakuan & $1524,02 \mathrm{~b}$ \\
\hline BNT 5\% & 80,51 \\
\hline
\end{tabular}

Keterangan : Nilai pada kolom yang sama dan diikuti huruf yang berbedamenunjukkan berbeda nyata berdasarkan Uji BNT pada taraf nyata $5 \%$, tn = tidak berbeda nyata, hsp $=$ hari setelah pembungaan .

Aplikasi ethephon berperan dalam mempercepat kemasakan buah sehingga tidak berpengaruh terhadap bobot buah. Hal tersebut sesuai dengan hasil penelitian Sakhidin dan Slamet (2011) bahwa aplikasi ethephon tidak berpengaruh terhadap bobot buah nanas. Oleh karena itu, bila melihat hasil uji kontras, maka peningkatan bobot buahterjadi karena pengaruh dari aplikasi $\mathrm{CaCl}_{2}$.

Pemberian kalsium telah terbukti berpengaruh terhadap pembelahan sel dan kekompakan buah (Mishra, 2002). Perbedaan ketersediaan unsur kalsium memberikan pengaruh terhadap pembentukan dinding sel karena pada masing-masing buah memiliki kemampuan yang berbeda dalam penggunaan ion $\mathrm{Ca}^{2+}$ sebagai komponen penyusun lamela tengah pada dinding sel. Lamela tengah merupakan daerah yang banyak mengandung pektin yang apabila berinteraksi dengan $\mathrm{Ca}^{2+}$ akan membentuk Ca pektat, yang berperan dalam menambah keterikatan antar sel (Nyakpa, 2008). Apabila keterikatan sel terjadi dalam jumlah cukup besar, maka akan terjadi jaringan molekul yang melebar dan buah menjadi kokoh 
padat berisi sehingga berpengaruh terhadap bobot buah (Ashari, 2006).

Menurut Hadiyati (2011) nanas jenis Cayenne ini memiliki ukuran buah yang lebih besar dibanding dengan jenis Pernambuco, Queen dan Spanish. Bobot buah memiliki genotip yang disesuaikan dan dipengaruhi oleh faktor lingkungan dan musim. Menurut Lisdiana dan Soemadi (2007) pada musim kemarau nanas jenis smooth cayenne memiliki ukuran buah yang lebih besar dibandingkan dengan nanas yang ditanam saat musim penghujan.

Pada penelitian yang dilakukan oleh Montalvo et al. (2017), ethephon tidak dapat memberikan pengaruh terhadap bobot buah cabai. Ethephon hanya dapat membantu untuk menghasilkan etilen dimana etilen ini langsung terdapat pada jaringan tanaman itu sendiri. sehingga semakin tinggi dosis ethephon yang digunakan, maka perubahan warna dan pelunakan warna buah akan semakin cepat.
Kadar air buah. Kadar air buah dipengaruhi oleh adanya interaksi antara perlakuan waktu aplikasi $\mathrm{CaCl}_{2}$ dengan dosis $\mathrm{CaCl}_{2}$ baik pada tingkat kemasakan luar buah 0\%, 25\%,maupun50\%. Data interaksi kadar air buah disajikan pada Tabel 3.

Kombinasi perlakuan dua kali waktu aplikasi $\mathrm{CaCl}_{2} 100$ dan 130 hsp dengan dosis $\mathrm{CaCl}_{2} 80 \mathrm{~kg}$ ha-1 menghasilkan kadar air buah yang tidak berbeda nyata dengan kombinasi perlakuan dua kali waktu aplikasi $\mathrm{CaCl}_{2} 100$ dan 130 hsp dan dengan dosis $\mathrm{CaCl}_{2} 100 \mathrm{~kg}$ ha $^{-1}$. Keduanya menghasilkan kadar air buah yang lebih rendah dibandingkan dengan perlakuan lain. Perlakuan aplikasi ethephon tidak berpengaruh nyata terhadap kadar air buah. Apabila ditinjau dari pengaruh perlakuan terhadap kontrol, tanaman yang diberikan perlakuan aplikasi $\mathrm{CaCl}_{2}$ dan ethephon menghasilkan kadar air dalam buah lebih rendah dibandingkan dengan kontrol (Tabel $4)$.

Tabel 3. Kadar air buah (\%) akibat interaksi perlakuan waktu aplikasi $\mathrm{CaCl}_{2}$ dan dosis $\mathrm{CaCl}_{2}$.

\begin{tabular}{|c|c|c|c|c|}
\hline \multirow{2}{*}{$\begin{array}{c}\text { Kemasakan luar } \\
\text { buah }\end{array}$} & \multirow{2}{*}{$\begin{array}{c}\text { Waktu Aplikasi } \mathrm{CaCl}_{2} \\
\text { (hsp) }\end{array}$} & \multicolumn{3}{|c|}{ Dosis $\mathrm{CaCl}_{2}\left(\mathrm{~kg} \mathrm{ha}^{-1}\right)$} \\
\hline & & 55 & 80 & 105 \\
\hline \multirow{4}{*}{$0 \%$} & 100 & $82,26 \mathrm{~cd}$ & $80,87 \mathrm{bc}$ & $80,03 \mathrm{~b}$ \\
\hline & $100+130$ & 80,31 bc & $77,74 \mathrm{a}$ & $76,37 \mathrm{a}$ \\
\hline & 130 & $83,02 \mathrm{~d}$ & $81,18 \mathrm{bcd}$ & $80,05 \mathrm{~b}$ \\
\hline & BNT 5\% & \multicolumn{3}{|c|}{1,82} \\
\hline \multirow{4}{*}{$25 \%$} & 100 & $83,30 \mathrm{~cd}$ & $81,73 \mathrm{bc}$ & $80,95 \mathrm{~b}$ \\
\hline & $100+130$ & $80,93 \mathrm{~b}$ & $78,74 \mathrm{a}$ & $78,56 \mathrm{a}$ \\
\hline & 130 & $84,06 \mathrm{~d}$ & $82,24 \mathrm{bcd}$ & $80,92 \mathrm{~b}$ \\
\hline & BNT 5\% & \multicolumn{3}{|c|}{2,12} \\
\hline \multirow{3}{*}{$50 \%$} & 100 & $82,89 \mathrm{~cd}$ & $81,39 \mathrm{~cd}$ & $81,01 \mathrm{bc}$ \\
\hline & $100+130$ & 81,09 bc & $78,90 \mathrm{ab}$ & $78,55 \mathrm{a}$ \\
\hline & 130 & $83,70 \mathrm{~d}$ & $81,75 \mathrm{~cd}$ & 81,19 bc \\
\hline
\end{tabular}

Keterangan :Nilai yang diikuti huruf yang sama menunjukkan tidak berbeda nyata berdasarkan Uji BNT pada taraf nyata $5 \%$, hsp $=$ hari setelah pembungaan.

Tabel 4. Kadar air buah (\%) akibat perlakuan aplikasi ethephon dan perbandingan perlakuan dengan kontrol.

\begin{tabular}{cccc}
\hline Perlakuan & \multicolumn{3}{c}{ Kadar air buah (\%) pada tingkat kemasakan luar buah } \\
\cline { 2 - 4 } & $0 \%$ & $25 \%$ & $50 \%$ \\
\hline Dosis Ethephon $\left(\right.$ ha $\left.^{-1}\right)$ & & & \\
0 & 80,69 & 81,64 & 82,03 \\
3 & 80,38 & 81,42 & 81,81 \\
\hline BNT 5\% & $0,84 \mathrm{tn}$ & $1,09 \mathrm{tn}$ & $1,1 \mathrm{tn}$ \\
\hline Kontrol vs Perlakuan & & & \\
Kontrol & $85,74 \mathrm{~b}$ & $84,70 \mathrm{~b}$ & $84,86 \mathrm{~b}$ \\
Perlakuan & $80,54 \mathrm{a}$ & $81,53 \mathrm{a}$ & $81,92 \mathrm{a}$ \\
\hline BNT 5\% & 3,53 & 2,15 & 2,00
\end{tabular}

Keterangan : Bilangan pada kolom yang sama dan diikuti huruf yang sama menunjukkan tidak berbeda nyata berdasarkan Uji BNT 5\%, tn = tidak berbeda nyata. 
Kadar air buah dipengaruhi oleh kandungan $\mathrm{Ca}$ dalam buah. Hasil penelitian menunjukkan bahwa terjadi interaksi antara perlakuan waktu aplikasi $\mathrm{CaCl}_{2}$ dengan dosis $\mathrm{CaCl}_{2}$ terhadap kadar air buah. Pada tingkat kemasakan luar buah $0 \%$, 25\%, dan 50\%, kombinasi perlakuan dua kali waktu aplikasi $\mathrm{CaCl}_{2} 100$ dan 130 hsp dengan dosis $\mathrm{CaCl}_{2} 80 \mathrm{~kg}$ ha-1 menghasilkan kadar air buah yang tidak berbeda nyata dengan kombinasi perlakuan dua kali waktu aplikasi $\mathrm{CaCl}_{2} 100$ dan 130 hsp dengan dosis $\mathrm{CaCl}_{2} 105 \mathrm{~kg}$ ha-1.Perlakuan tersebut menghasilkan kadar air buah yang lebih rendah dibandingkan dengan perlakuan lain (Tabel 4).

Aplikasi ethephon tidak berpengaruh nyata terhadap kadar air buah, baik pada tingkat kemasakan luar buah $0 \%, 25 \%$ dan $50 \%$. Pengaruh perlakuan terhadap kontrol menunjukkan bahwa tanaman yang diberi perlakuan aplikasi $\mathrm{CaCl}_{2}$ dan ethephon menghasilkan kadar air buah yang lebih rendah dibandingkan kontrol. Hal tersebut sesuai hasil penelitian Mawardi (2005) yang menunjukkan bahwa aplikasi $\mathrm{CaCl}_{2}$ prapanen dapat menurunkan kadar air buah tomat. Kalsium dapat menurunkan permeabilitas membran terhadap air. Hal tersebut mengakibatkan aktivitas respirasi menurun sehingga kalsium dikenal sebagai ion pengendali respirasi. Konsentrasi $\mathrm{CaCl}_{2}$ yang semakin besar akan menghasilkan kadar air yang semakin kecil (Susanto dan Saneto, 2004).

\section{Kesimpulan}

1. Terdapat pengaruh interaksi antara waktu aplikasi $\mathrm{CaCl}_{2}$ dan dosis $\mathrm{CaCl}_{2}$ terhadap parameter kadar air buah.

2. Perlakuan dua kali waktu aplikasi $\mathrm{CaCl}_{2}$ pada 100 dan 130 hsp dapat menghasilkan bobot buah sebesar 1619,18 kg.

3. Perlakuan ethephon tidak memberikan pengaruh terhadap panjang buah, bobot buah, dan kadar air buah.

\section{Ucapan Terima Kasih}

Ucapan terima kasih ditujukan kepada Universitas Tribhuwana Tunggadewi yang telah memberikan kesempatan untuk melaksanakan penelitian.

\section{Daftar Pustaka}

Ashari, S., .2006. Hortikultura Aspek Budidaya, UI Press, Jakarta

Astuti, N.K., M.D. Maghfoer, dan R. Soelistyono. 2013. Aplikasi kalsium klorida dan ethephon dalam upaya peningkatan kualitas buah nanas (Ananas comosus (L.) Merr.).JKTI, 15 (1): 41 - 48.

Badan Pusat Statistik.2017. Kabupaten Malang Dalam Angka 2017. Badan Pusat Statistik. http://www. bps.go.id [10 Oktober 2020]

Bartholomew, D. P., R, E Pauli and K. G Rohrbach. 2003 the pineapple botany, production and uses. University of Hawaii at manoa Honolulu USA. CABI Publishing. New York.

Basuki, M.; R. Jatmika dan S. Loekito. 2009. Pengaruh Aplikasi $\mathrm{CaCl}_{2}$ Setelah Forcing terhadap Serangan Penyakit Buah. PT. Great Giant Pineapple. Lampung.

Bondad, N.D. 2006. Respon of Some Tropical and Subtropical Fruit to Pre and PostHarvest Applications of Ethephon. Economic Botany 30: 67- 80

Cahyono, E. A., Ardian, F. Silvina. 2014. Pengaruh pemberian beberapa dosis pupuk NPK terhadap pertumbuhan berbagai sumber tunas tanaman nanas (Ananas comosus L Merr) yang ditanaman diantara tanaman sawit belum menghasilkan di lahan gambut. Jurnal online mahasiswa faperta 1 (2) : 1-13

Hadiyati, S., dan N.L.P. Indriyani. 2008. Budidaya Nenas. Balitbu.Solok.

Hadiyati, S., S Yuliati dan Jumjunidang. 2011. Evaluasi pertumbuhan dan hasil beberapa kandidat varietas nenas rendah oksalat dan manis tanpa duit. Balai penelitian tanaman buah tropika. Solok. J. hortikultura. 21 (4) : 315- 323

Istiqomah.2017. Kajian Iklim (Suhu Kardinal dan Curah Hujan) Terhadap Pembentukan Buah Alami (Natural fruit) Pada Tanaman Nanas (Ananas comosus L.).Sarjana thesis.Universitas Brawijaya.

Leal, F. and G. D. Coppens. 1996. Pineapple. In J. Janick dan J.N. Moore (eds.). Fruit Breeding, vol. 1 : Tree and Tropical Fruits. John Wiley and Sons, New York. p 515-557

Lisdiana dan W, Soemadi. 2007. Budidaya Nanas Pengolahan dan Pemasaran. Aneka Ilmu, Semarang 
Mawardi. 2005. Pengaruh Perendaman Buah dalam Larutan $\mathrm{CaCl}_{2}$ terhadap Kualitas Buah Tomat (Lycopersicon esculentum). Jurnal Budidaya Pertanian, 20 (2) : 112 115.

Miranda, C. A., Sobardini, M., dan Etik, W. T. 2019. Pengaruh metode pengaplikasian dan konsentrasi kalsium klorida $\left(\mathrm{CaCl}_{2}\right)$ terhadap vase life bunga potong anggrek dendrobium 'sonia. Jurnal Agritech, Vol. 21 No.1. Hal. 32-43.

Mishra, M. 2002. Lead Acetate Induced Citotoxicity in Male Germinal Cell of Swiss Mice. Swiss.p.291-294.

Montalvo, E., H. S. Garcia, B. Tovar dan M. Mata. 2017. Application of exogenous ethphon on postharvest ripening of refrigerated 'Ataulfo' mangies. Food Sci. Technol. 40:1466-1472.

Nyakpa,M.Y. 2008. Kesuburan Tanah. Universitas Lampung.

Pemkab Malang. 2010. RPIJM Kabupaten Malang 2011-2015. Pemkab Malang. Malang.

Rai, I.N., R. Poerwanto, L.K. Darusman., dan B.S. Purwoko. 2004. Pengaturan Pembu- ngaan Tanaman Manggis (Garcinia mangostana L.) di Luar Musim dengan Strangulasi, serta Aplikasi Paklobutrazol dan Etepon. Vol 18.

Sakhidin dan Slamet, R.S. 2011. Produksi Durian di Luar Musim melalui Pemberian Paklobutrazol dan Etepon. Program Studi Agroteknologi. Fakultas Pertanian. UNSUD. Purwakarta

Sidauruk, C., O., Jasmani, G dan Justin, N. 2013. pengaruh konsentrasi dan frekuensi aplikasi etephon terhadap pertumbuhan dan produksi tanaman mentimun (cucumis sativus 1.). jurnal online agroekoteknologi. vol.2, no.1: 54-63.

Susanto, T dan B. Saneto. 2004. Teknologi Pengolahan Hasil Pertanian. Bina Ilmu. Surabaya.

Syah, M. A. L., E. Anom, S. L. Putra. 2016 pengaruh pemberian beberapa dosis pupuk NPK tablet terhadap pertumbuhan dan produksi tanaman nanas (Ananas comosus L Merr) di lahan gambut. Jurusan Agroteknologi, Fakultas Pertanian. Universitas Riau. Jurnal Online Mahasiswa Faperta 2 (1) : 1-6 